PATIK : Jurnal Hukum

https://ejournal.uhn.ac.id/index.php/patik

Volume 10 Nomor 01, April 2021 Page : 69 - 78

p-issn : 2086 - 4434

\title{
PERTANGGUNGJAWABAN PERUSAHAAN ATAS KETERLAMBATAN PEKERJAAN KONTRAKTOR DI BIDANG PENGADAAN BARANG DAN JASA BERDASARKAN SURAT PERJANJIAN NO: 014.PJ/PT/DAN.02.01/SLBA/2017 (STUDI KASUS CV PUTRI MANDIRI SEJATI MEDAN)
}

\author{
Christin Veronica Tambunan, Marthin Simangunsong, Uton Utomo \\ Fakultas Hukum, Universitas HKBP Nommensen \\ marthinsimangunsong@gmail.com
}

\begin{abstract}
Abstrak
Keterlambatan pekerjaan kontraktor di bidang pengadaan barang dan jasa sering menimbulkan permasalahan. Perjanjian pengadaan barang dan jasa disusun terlebih dahulu oleh pemberi pekerjaan, Tanggungjawab Kontraktor CV Putri Mandiri Sejati Medan dalam pengadaan barang dan jasa yaitu lahir berdasarkan prestasi yang diatur dalam Pasal $1234 \mathrm{Kitab}$ Undang-Undang Hukum Perdata. Kewajiban utama yaitu melakukan pembayaran sesuai dengan nilai kontrak dari pihak pemborong jika pemborong telah menyelesaikan pekerjaannya. Sedangkan Kewajiban tambahan tambahan meliputi Membayar uang muka pekerjaan (down payment) kepada pihak pemborong setelah menerima jaminan pelaksanaan dari pihak pemborong. Keputusan badan arbitrase ini mengikat kedua belah pihak, dan biaya penyelesaian perselisihan yang dikeluarkan akan dipikul bersama. Apabila putusan Badan Arbitrase tidak dapat diterima oleh para pihak maka perselisihan akan diteruskan dan diputuskan melalui Pengadilan Negeri setempat. Dalam prakteknya selama ini, setiap perselisahan dalam pelaksanaan perjanjian pemborongan dapat diselesaikan secara musyawarah dan mufakat diantara para pihak dan belum pernah diselesaikan melalui Badan Arbitrase atau pengadilan
\end{abstract}

Kata Kunci : Kontraktor, Pemborong, Perjanjian, Pengadaan Barang dan Jasa

\begin{abstract}
Delays in contractor work in the procurement of goods and services often cause problems. In this case the formulation of the problem is how to implement the agreement for the procurement of goods and services at CV Putri Mandiri Sejati Medan, what are the responsibilities of the contractor CV Putri Mandiri in the procurement of goods and services, the efforts taken by related parties if problems arise in the implementation of the procurement of goods and services at CV. Putri Mandiri Sejati Medan. Regarding the rights and obligations of the parties in the servo valve procurement agreement between PLN (PERSERO) and CV PUTRI MANDIRI SEJATI in the Tapanuli Tengah area consists of main obligations and additional obligations. Where the main obligation is to make payments according to the contract value of the contractor if the contractor has completed his work. Whereas additional additional obligations include paying down payments to the contractor after receiving the implementation guarantee from the contractor. If the dispute cannot be resolved by deliberation, it will be resolved by an arbitase body. The decision of the arbitration body is binding on both parties, and the costs of dispute resolution incurred will be shared. If the decision of the Arbitration Board cannot be accepted by the parties, the dispute will be forwarded and decided through the local District Court. In practice so far, every dispute in the implementation of a contracting agreement can be resolved by deliberation and consensus between the parties and has never been resolved through an Arbitration Board or court.
\end{abstract}

Keywords: contractor, agreement, Procurement of Goods and Services 


\section{Pendahuluan}

Negara Republik Indonesia adalah sebuah Negara Hukum. Dalam pembukaan Undang-Undang Dasar Negara Republik Indonesia Tahun 1945 pada Pasal 1 Ayat (3), mengatur bahwa "Indonesia adalah Negara Hukum".Artinya, semua tindakan harus dilakukan berdasarkan hukum yang berlaku dan perbuatan tersebut dapat dipertanggungjawabkan pula. ${ }^{1}$ Hukum adalah aturan dan baru ada karena adanya masyarakat yang terorganisasi, sehingga hukum itu adalah aturan yang dibuat oleh mereka yang memang ditugaskan untuk membuatnya meskipun dalam bentuknnya yang masih sangat sederhana. ${ }^{2}$ Tujuan hukum adalah agar terciptanya keteraturan dan ketertiban dalam kehidupan bermasyarakat. Konsep negara hukum yang dianut indonesia tidak dapat dipisahkan dari nilai-nilai moral pancasila, sebab pancasila merupakan roh dan negara sebagai badannya.

Pasal1 huruf (b) Undang-undang No.3 Tahun 1982 tentang Wajib Daftar Perusahaan, bahwa perusahaan adalah "Setiap bentuk usaha yang menjalankan setiap jenis usaha yang bersifat tetap dan terus-menerus dan didirikan, bekerja, serta berkedudukan dalam wilayah negara Indonesia untuk tujuan memperoleh keuntungan atau laba". ${ }^{3}$ Menurut Molengraaff perusahaan adalah keseluruhan perbuatan yang dilakukan secara terus-menerus, untuk memperoleh penghasilan, bertindak keluar, dengan cara memperdagangkan, menyerahkan atau mengadakan perjanjian-perjanjian perdagangan ${ }^{4}$.

Dalam ketentuan Pasal 1313 Kitab Undang-Undang Hukum Perdata menyebutkan "Perjanjian adalah suatu perbuatan dengan mana satu orang atau lebih mengikatkan dirinya terhadap satu orang atau lebih lainnya".Adapun diatur mengenai unsur-unsur perjanjian yaitu sebagai berikut adanya perbuatan hukum, persesuaian pernyataan kehendak dari beberapa orang, serta persesuaian kehendak harus dipublikasikan/dinyatakan. ${ }^{5}$

Penyedia yang bergerak dalam bidang pemasokan barang disebut pemasok atau leveransir,sedangkan dalam bidang jasa pemborongan disebut pemborong atau kontraktor.Pengadaan barang dan jasa melibatkan beberapa pihak,yaitu pihak pembeli atau pengguna dan pihak penjual atau penyedia Barang dan Jasa.Pembeli dan pengguna barang dan jasa adalah pihak yang membutuhkan barang dan jasa. Dalam pelaksanaan pengadaan, pihak pengguna adalah pihak yang meminta atau memberi tugas kepada pihak penyedia untuk memasok atau membuat barang atau melaksanakan pekerjaan tertentu.

Pengguna barang dan jasa dapat merupakan suatu lembaga / organisasi dan dapat pula orang perseorangan, yang tergolong lembaga antara lain: Instansi Pemerintah (Pemerintah Pusat, Pemerintah, Provinsi, Pemerintah Kabupaten, Pemerintah Kota), Badan Usaha (BUMN,BUMD,Swasta) dan organisasi masyarakat. Adapun yang tergolong orang perseorangan adalah individu atau orang yang membutuhkan barang dan jasa. ${ }^{6}$

Oleh sebab itu salah satu pihak mempunyai pilihan untuk menerima atau menolak perjanjian tersebut.Dalam konteks inilah praktek perjanjian pengadaan barang dan jasa menurut penulis perlu dicermati lebih lanjut dari sisi aspek hukumnya. Karena pengadaan

${ }^{1}$ Simamora, Janpatar., Tafsir Makna Negara Hukum dalam Perspektif Undang-Undang Dasar Negara Republik Indonesia Tahun 1945, Jurnal Dinamika Hukum FH Universitas Jenderal Soedirman, Vol. 14 No. 3 September 2014, hlm. 547-561.

${ }^{2}$ Peter Mahmud Marzuki, 2008, Pengantar Ilmu Hukum, Prenada Media Group, Jakarta, hal.41-43.

${ }^{3}$ Kansil dan Cristine, 1995, Hukum Perusahaan Indonesia, Pradnya Paramita, Jakarta, hal.1-2.

${ }^{4}$ Pengertian Perusahaan menurut para ahli, diakses pada tanggal 24 Juli 2020 dari https://www.google.co.id/search?q=pengertian+perusahaan+menurut + para + ahli\&ie=utf

${ }^{5}$ KUHPerdata Burgerlijk Wetbook, BAB II, Perikatan Yang Lahir dari Kontrak / Persetujuan Bagian I.

${ }^{6}$ Adrian Sutedi,Aspek Hukum Pengadaan Barang Dan Jasa Dan Berbagai Permasalahannya ,Sinar Grafika Offset, Jakarta , 2008 ,hlm. 4 -5 . 
barang dan jasa selama ini hanya dipandang seakan akan formalitas belaka dalam suatu pelaksanaan proyek pengadaanpadahal perjanjian tersebut merupakan dasar pelaksanaan kegiatan. Berdasarkan uraian di atas yang menjadi rumusan masalah dalam penulisan penelitian ini adalah :

1. Bagaimanakahpelaksanaan perjanjian pengadaan barang dan jasa di CV.Putri Mandiri Sejati Medan?

2. Bagaimanakah tanggung jawab kontraktor CV. Putri Mandiri Sejati dalam pengadaan barang dan jasa?

\section{Tinjauan Pustaka}

Istilah Kontrak atau Perjanjian berasal dari bahasa inggris, contract atau "overeenkomst" (Belanda), yang diterjemahkan dengan istilah "Perjanjian" yang diatur di dalam Pasal 1313 Kitab Undang-Undang Hukum Perdata BukuIII. Dalam perjanjian Pasal 1313 Kitab-Kitab Hukum Perdata disebutkan sebagai berikut: Suatu persetujuan adalah perbuatan dengan mana satu orangatau lebih mengikatkan dirinya terhadap satu orang atau lebih. Dalam rumusan tersebut digunakan istilah persetujuan dan bukan perjanjian. ${ }^{7}$

Definisi yang hampir serupa tentang perjanjian juga dikemukakan oleh Halim, bahwa Perjanjian adalah Suatu hubungan antara satu pihak dengan yang lain dalam lalu lintas hukum yang biasanya mengatur hak/kewajiban timbal balik antar merekayangberkenaan dengan barang ataujasa. ${ }^{8}$

Menurut R. Wirjono Prodjodikoro mengartikan bahwa perjanjian sebagai suatu hubungan hukum mengenai harta benda antara kedua belah pihak, dalam manasatu pihak berhak untuk menuntut pelaksanaanjanjiitu. ${ }^{9}$ Sedangkan menurut Abdul Kadir Muhammad merumuskan kembali definisi Pasal 1313 Kitab Undang-Undang Hukum Perdatasebagai berikut,bahwa yangdisebut perjanjian adalah suatu persetujuan dengan mana dua orang atau lebih saling mengikatkan diri untuk melaksanakan sesuatu hal dalam lapangan harta kekayaan. ${ }^{10}$ Secara Umum,kontrak atau perjanjian adalah suatu keadaan dimana kedua belah pihak ataulebih melakukan perjanjian yang bentuknya tertulis untuk dilaksanakan bersama pada suatu kegiatan. ${ }^{11}$

Jika suatu perjanjian diamati dan diuraikan dalam unsur-unsur yang ada di dalamnya, maka unsur- yang ada di sana dapat diklasifikasikan sebagai berikut :

a. Unsur Esensialia.

Unsur essensialia adalah sesuatu yang harus ada yang merupakan hal pokok sebagai syarat yang tidak boleh diabaikan dan harus dicantumkan dalam suatu perjanjian.Bahwa dalam suatu perjanjian haruslah mengandung suatu ketentuan tentang prestasi-prestasi.Hal ini adalah penting disebabkan hal inilah yang membedakan antara suatu perjanjian dengan perjanjian lainnya.

b. Unsur Naturalia.

Unsur Naturalia adalah ketentuan hukum umum, suatu syarat yangbiasanyadicantumkan dalam perjanjian.Unsur-unsur atau hal ini biasanyadijumpaidalam perjanjian-perjanjian tertentu,dianggap ada kecualidinyatakan sebaliknya yang dimana merupakan unsur yang wajib

\footnotetext{
${ }^{7}$ R. Subekti, Hukum Perjanjian, Intermasa, Jakarta, 1963, hal. 1.

${ }^{8}$ Abdul Khakim,S.H.,M.Hum. , Aspek Hukum Perjanjian Kerja,Peraturan Perusahaan, Dan Perjanjian Kerja Bersama (PKB) ,PT Citra Aditya Bakti, Bandung,2017,Hal 41.

${ }^{9}$ R. Wiryono Projodikoro, Asas-asas Hukum Perjanjian, Sumur, Bandung, 1993, hal. 9.

${ }^{10}$.Abdul Kadir Muhammad, Hukum Perikatan, Citra Aditya Bakti, Bandung, 1992, hal. 78.

${ }^{11}$ Toman Sony Tambunan, Hukum Bisnis, Prenamedia Group , Jakarta , 2019, Hal. 55
} 
dimilikioleh suatu perjanjian yang menyangkut suatu keadaan yang pasti ada setelahdiketahui unsur essensialianya.Jadi terlebih dahulu harus dirumuskan unsureessensialianyabaru kemudian dapat dirumuskan unsur naturalianya.Misalnyajual beli unsur naturalianya adalah bahwa si penjual harus bertanggung jawabterhadap kerusakan-kerusakan atau cacat-cacat yang dimiliki oleh barang yangdijualnya.

c. Unsur Accidentalia.

Yaitu berbagai hal khusus (particular) yang dinyatakan dalamperjanjian yang disetujui oleh para pihak. Accidentalia artinya bisa ada ataudiatur, bisa juga tidak ada, bergantung pada keinginan para pihak,merasaperlu untuk memuat ataupun tidak. Selain itu aksidentalia adalah unsur pelengkap dalam suatu perjanjian yang merupakan ketentuan-ketentuan yangdapat diatur secara menyimpang oleh para pihak, sesuai dengan kehendak parapihak yang merupakan persyaratan khusus yang ditentukan secara bersama-sama oleh para pihak. Jadi unsur aksidentalia lebih menyangkut mengenaifaktor pelengkap dari unsur essensialia dan naturalia, misalnya dalam suatuperjanjian harus ada tempat dimana prestasi dilakukan. ${ }^{12}$ Syarat sahnya perjanjian diatur dalam Pasal 1320 Kitab Undang -UndangHukum Perdata Pasal 1320 Kitab Undang-Undang Hukum Perdata atau Pasal 1365 Buku IV NBW(BW Baru) Belanda. Pasal 1320 KitabUndang-Undang Hukum Perdata menentukan empat syarat sahnya perjanjian,yaitu :

a. Kesepakatan (Toesteming/izin) Kedua Bela Pihak.

Syarat yang pertama sahnya kontrak adalah adanya keseapakatan atau konsensus pada pihak.Kesepakatan ini diatur dalam pasal 1320 ayat (1) Kitab Undang-Undang Hukum Perdata.Yang dimaksud dengan kesepakatan adalah persesuaian pernyataan kehendak antara satu orang atau lebih dengan pihak lainnya. Yang sesuai itu adalah pernyataannya,karena kehendak itu tidak dapat dilihat/diketahui orang lain.

b. Kecakapan Bertindak .

Kecakapan bertindak adalah kecakapan atau kemampuan untuk melakukan perbuatan hukum.Perbuatan hukum adalah perbuatan yang akan menimbulkan akibat hukum.Orang-Orang yang akan mengadakan perjanjianharuslah orang-orang yang cakap dan mempunyai wewenang untuk melakukan perbuatan hukum.Orangorang yang akan mengadakan perjanjian haruslah orang-orang yang cakap dan mempunyai wewenang untuk melakukan perbuatan hukum,sebagaimana yang telah ditentukan oleh undang-undang.Orang yang cakap dan berwenang untuk melakukan perbuatan hukum adalah orang yang sudah dewasa.Ukuran kedewasan adalah telah berumur 21 tahun dan atau sudah kawin.

c. Adanya Objek Perjanjian (Onderwerp der Overeenskomst).

Di dalam berbagai literatur disebutkan bahwa yang menjadi objekperjanjian adalah prestasi (pokok perjanjian ).Prestasi adalah apa yang menjadi kewajiban debitur dan apa yang menjadi hak kreditur.

d. Adanya Causa yang Halal.

Dalam Pasal 1320 Kitab Undang-Undang HukumPerdatatidakdijelaskan pengertian causa yang halal. Didalam Pasal 1337 Kitab Undang-Undang Hukum Perdata hanya disebutkan causa yang terlarang. Suatu sebab adalah terlarang apabila bertentangan dengan undang-undang, kesusilaan dan ketertiban umum. Hoge raad sejak tahun 1927 mengartikan orzaak sebagai suatu yang menjadi tujuan para pihak

${ }^{12} \mathrm{http}: / /$ www.rudipradisetia.com/2010/11/unsur-unsur-dalam-perjanjian-dalam.html 


\section{Metode}

Penelitian ini merupakan penelitian yuridis normatif, ${ }^{13}$ yaitu suatu penelitian hukum yang dilakukan dengan cara meneliti data sekunder ${ }^{14}$ atau data yang bersifat kepustakaan yang diperoleh dari perpustakaan ilmiah atau sejumlah intansi terkait terhadap objek yang diteliti. Semua data yang telah didapatkan baik data primer maupun data sekunder serta semua informasi yang telah didapatkan akan dianalisa oleh penulis secara analisa kualitatif, yang dimana data yang diperoleh akan disusun secara sistematis kemudian dianalisis secara kualitatif untuk mencapai kejelasan masalah yang dibahas.

\section{Pembahasan Dan Hasil}

Pelelangan umum melalui Penunjukan Langsung berdasarkan Keputusan Direksi PT PLN (Persero) No.3056.K/SDM.00.03/DIR/2016 dan berdasarkan Surat Kuasa General Manajer PT PLN (Persero) Pembangkitan Sumatera Bagian Utara No.002.Sku/SDM.0801/KITSBU/2017 dengan CV. Putri Mandiri Sejati Medan adalah: Pengadaan barang dan jasa dengan cara mengundang atau menunjuk langsung 1 (satu) Penyedia Barang danJasa yang diutamakan dari dalam daftar Penyedia barang dan Jasa Perusahaan yang dinilai mampu dan memenuhi kualifikasi yang dipersyaratkan. Pengadaan barang dan jasa dengan menggunakanmetode penunjukan langsung ini harus dilakukan klarifikasi (bila diperlukan) serta negosiasi baik teknis maupun harga dalam upaya mendapatkan barang dan jasa yang berkualitas dengan harga yang wajar (hargaliv), menguntungkan perusahaan dan dapatdipertanggungjawabkan.

Pelelangan umum berdasarkan Keputusan Direksi PT. PLN (Persero) No.3056.K/SDM.00.03/DIR/2016 dan berdasarkan Surat Kuasa General Manajer PT. PLN (Persero) Pembangkitan Sumatera Bagian Utara No.002.Sku/SDM.08.01/KITSBU/2017dengan CV Putri Mandiri Sejati Medan adalah : Metode pengadaan barang dan jasa yang dilakukan dengan cara mengundang Penyedia Barang dan Jasa yang sudah tercatat dalam daftar Penyedia Barang dan Jasa Perusahaan yang memenuhi kualifikasi yang dipersyaratkan,melalui papan pengumuman resmi Kantor Pusat dan/atau Unit Bisnis. Metode pelelangan terbatas dilakukan untuk pengadaan barang danjasa yang komplek (lingkup tugasnya termasuk pekerjaan enjiniring dan/atau menggunakan teknologi tinggi dan/atau mengandung risiko tinggi) serta dinilai cukup banyak Penyedia Barang dan Jasa yang tercatat dalam daftar Penyedia Barang dan Jasa Perusahaan dapat memenuhi kualifikasi yang dipersyaratkan. Pengadaaan Barang dan Jasa dengan metode ini tidak dilakukan negosiasi harga.

\footnotetext{
${ }^{13}$ Penelitian hukum normatif pada umumnya memiliki ciri-ciri sebagai berikut: (a) deskriptif analitis dengan pendekatan yuridis normatif; (b) tahapan penelitian adalah melalui penelitian kepustakaan, yaitu mencari data sekunder dengan menggunakan bahan hukum primer, sekunder dan tertier; (c) konsep, perspektif, teori dan paradigma yang menjadi landasan teoritikal penelitian mengacu pada kaidah hukum yang ada dan berlaku pada ajaran hukum (dari berbagai pakar hukum yang terkemuka); (d) jarang menampilkan hipotesis; (e) analisis data dilakukan secara kualitatif, artinya tanpa menggunakan angka, rumus, statistik dan matematik. Lili Rasjidi, Pengantar Metode Penelitian dan Penulisan Karya Ilmiah Hukum, Monograf atau Diktat Kuliah pada Program Doktor Ilmu Hukum Universitas Padjadjaran, Bandung, 2007, hlm. 7. Lihat juga Lili Rasjidi, Menggunakan Teori/Konsep dalam Analisis di Bidang Ilmu Hukum, Monograf atau Diktat Kuliah pada Program Doktor Ilmu Hukum Universitas Padjadjaran, Bandung, 2007, hlm. 6-7.

${ }^{14}$ Zulfadli Barus, "Analisis Filosofis Tentang Peta Konseptual Penelitian Hukum Normaatif dan Penelitian Hukum Sosiologis," Jurnal Dinamika Hukum, FH Unsoed, Vol. 13 No. 2, hlm. 309, Mei 2013.
} 
Pelelangan umum dengan cara pengadaan langsung berdasarkan Keputusan Direksi PT. PLN (Persero) No. 3056.K/SDM.00.03/DIR/2016 dan berdasarkan Surat Kuasa General Manajer PT. PLN (Persero) Pembangkitan Sumatera Bagian Utara No.002.Sku/SDM .08.01/KITSBU/2017dengan CV. Putri Mandiri Sejati Medan adalah : Pengadaan adalah pengadaan barang dan jasa dengan nilai sampai dengan Rp. 250.000.000,- (Dua Ratus Lima puluh juta rupiah)yang dilakukan dengan cara menunjuk langsung 1 (satu) Penyedia Barang dan Jasa, diutamakan dari dalam Daftar Penyedia Barang dan Jasa Perusahaan, yang dinilai mampu dan memenuhi kualifikasi yang dipersyaratkan.

Dalam praktek perjanjian pengadaan barang dan jasa dibuat dalam bentuk akta di bawah tangan bukan dalam bentuk otentik (akta notariil). Dimana draft perjanjian telah dipersiapkan terlebih dahulu oleh pihak pengguna jasa dalam hal ini oleh PT. PLN (PERSERO) Pembangkitan Sumatera Bagian Utara Sektor Pembangkitan Labuhan Angin dibuatnya perjanjian pengadaan barang dan jasa tersebut dalam bentuk akta di bawah tangan didasarkan oleh efesiensi waktu dan biaya.

Dalam merancang perjanjian panitia pengadaan barang dan jasa di lingkungan PT PLN (PERSERO) Pembangkitan Sumatera Bagian Utara Sektor Pembangkitan Labuhan Angin menggunakan standard kontrak atau contoh Surat Perjanjian Kerja (SPK). Hal-hal yang menyangkut pelaksanaan perjanjian pengadaan barang dan jasa merupakan ketentuan standard yang telah ditetapkan oleh Kedua belah pihak. Langkah ini dilakukan dengan tujuan untuk menciptakan syarat dan kondisi yang sama dalam setiap perjanjian pengadaan barang dan jasa kepada setiap penyedia jasa. Sehingga tidak terdapat diskriminasi perlakuan syarat dan kondisi dalam perjanjian pengadaan barang dan jasa yang harus dipatuhi oleh pihak rekanan.

Setiap kontrak pengadaan barang dan jasa dibuat terdiri dari 2 (dua) rangkap yang sama isi dan kekuatan hukumnya, masing-masing bermeterai cukup dan ditanda tangani oleh para pihak terkait. Dari perjanjian pengadaan barang dan jasa tersebut di atas dapat disimpulkan pihak kontraktor tinggal menandatangani perjanjian tersebutsesuai dengan hasil negoisasi yang berartisehingga prinsip "taked or lived" yang biasa terjadi dalam suatu perjanjianstandard berlaku juga terhadap perjanjian pengadaan barang dan jasa,walaupun sebenarnya perjanjian pengadaan barang dan jasa bukanlah perjanjian baku atau standar karena pihak kontraktor mempunyai hak untuk ikut serta dalam merumuskan perjanjian.

Pihak kontraktor atau pemborong cendrung mengabaikanmekanisme perancangan kontrak, isi kontrak dan akibat-akibat hukumnya. Hal ini dapat diketahui berdasarkan hasil penelitian dilapangan, pihak kontraktor hanya berorientasi kepada proyek dalam arti kontraktor hanya mempunyai target menjadi pemenang tender,sedangkan permasalahan kontrak pengadaan barang dan jasa yang akan ditandatangani dalam setiap proyek yang diperolehnya dilakukan tanpa negosiasi lebih lanjut.Hal ini merupakan indicator lemahnya posisi tawar pihak kontraktor dalam pembuatan perjanjian pengadaan barang dan jasa.

Salah satu bagianyang terpenting dalam suatu perjanjian adalah isi perjanjian itu sendiri. Dari pasal-pasal yang termuat dalamsuatu isi perjanjian dapat menggambarkan kondisi dan informasi tentang apa yang disepakati oleh para pihak yang membuatnya baik secara tersurat maupun tersirat. Pembatasan terhadap asas kebebasan berkontrak dalam perjanjian pengadaan barang dan jasa harus dapat dimaknai dalam arti positif karena setidaknya dengan pembatasan tersebut pemerintah telah berupaya untuk memberikan "guide line" bagi penyusunan perjanjian pengadaan barang dan jasa. Kesembilan belasklausula tersebut bukanlah menjadi isi keseluruhan perjanjian para pihak dapat menambahkan klausula-klausula lain sesuai dengan kondisi yang telah disepakati. 
Dalam penyusunan isi suatu kontrak pada umumnya perlu diatur serangkaian "ruleof game" untuk dapat mencerminkan kenyataan atau maksud perjanjian yang dibuat.

Dalam pelaksanaan perjanjian pemborongan terdapat beberapa masalah yang sering terjadi di lapangan yang terkait dengan tanggung jawab dan resiko dari pihak pemborong atau kontraktor. Dalam Perjanjian pengadaan barang dan jasa PT PLN (PERSERO) Pembangkitan Sumatera Bagianutara Sektor Pembangkitan Labuhan Angin dan penyedia jasa atau pihak kantraktor (CV. Putri Mandiri Sejati Medan),dimungkinkan bahwa kontraktor menyerahkan pemborongan pekerjaan tersebut kepada pemborong lain yang merupakan sub-kontraktor berdasarkanperjanjian khusus antara pemborongdan subkontraktor.Permasalahan tersebut adalah hal-hal yang berkenaan dengan keberadaan subkontraktor dalam pelaksanaan pekerjaan, penyimpangan pekerjaan dari perencanaan dan keterlambatan penyelesaian proyek.

Pihak Kontraktor tidak dibenarkan mensub-kontraktor seluruh pekerjaan dan atau sebagian pekerjaan utamanya kepada pihak lain atau pemborong lainnya, kecuali disubkontrakkan kepada penyedia jasa spesialis. Dan apabila ketentuan ini dilanggar,maka penyedia barang atau jasa akan diberikan peringatan secara tertulis oleh pemberi pekerjaan supaya kembali mengikuti ketentuan-ketentuan sesuai dengan surat perjanjian dan dapat dikenakan sanksi berupa denda maupun ganti kerugian yang bentuk dan besarnya sesuai denganketentuan yang diatur dalam perjanjian kerja.

Pemborong (rekanan) yang mengalihkan pekerjaan(mensub-kontrakkan) ataupun yang menerima pengalihan pekerjaan akan dikeluarkan daridaftar rekanan Mampu. Hal Ini berarti pemborong hanya berhak mensub-kontrakkan sebagian pekerjaan kepada pemborong lain dan bukan seluruh pekerjaan utamanya. Sub-kontraktor yang menerima pengalihan pekerjaan juga tidak diperkenankan mensub-kontrakkan lagi,baik sebagian maupun keseluruhan pekerjaan kepada kontraktor lain. Segala akibat yang ditimbulkan atas mensub-kontraktor pekerjaan tetap menjadi tanggung jawab pihak pemborong.

Apabila kontraktor melaksanakan pekerjaan tidak sesuai denganperencanaan tehnis atasyang telah diatur dalam perjanjian maka kontraktor harus memberikan ganti rugi dan memperbaiki bagian hasil pekerjaannya yang tidak sesuai tersebut. Penyimpangan terhadap pelaksanaan pekerjaan tersebut bisa dikarenakan penggunaan bahan-bahan material dan peralatan, yang mengakibatkan terjadinya penyimpangan mutu pekerjaan, ataupun terjadi keterlambatan dalam menyelesaikan pekerjaan maka kontraktor dapat dikenakan sanksi keterlambatan yaitu:

a. Apabila penyerahan pekerjaan melampaui dari batas waktu yang telah ditetapkan dalamsurat kontrak,maka penyedia barang dan jasa dikenakan denda keterlambatan $1 \%$ (Satu Permil) untuk setiap hari kelender keterlambatandari jumlah harga total dengan maksium denda sebesar 5\% (Lima persen) dari seluruh biaya pelaksaan dalam nilai surat perjanjian.

b. Setelah berakhir batas waktu yang telah ditentukan,pihak penyedia barang dan jasa tidak dapat menyelesaikan pekerjaan, maka pemberi pekerjaan akan memberikan surat peringatan pertama.

c. Apabila 14 (empatbelas hari) setelah surat peringatan pertama pihak penyedia barang dan jasa juga tidak dapat menyelesaikan pekerjaannya, maka pihak pemberi kerja dapat memberikan surat peringatan kedua dan apabila 14 (empatbelas hari) setelah surat peringatan kedua belum juga menyelesaikan pekerjaannya, maka pemberi pekerjaan akan mengeluarkan surat peringatan ketiga atau sewaktu-waktu dapat memutuskan perjanjian secara sepihak dan menyampingkan Pasal 1266 - 1267 Kitab Undang-Undang Hukum Perdata dan penyedia barang dan jasa dikenakan skorsing tidak boleh mengikuti proyek- 
proyek di PT PLN (PERSERO) Sektor Pembangkitan Sumaterabagian Utara Sektor Pembangkitan Labuhan Angin selama 6 (enam) bulan.

d. Apabila 14 (empatbelas hari) setelah surat peringatan ketiga pihak penyedia barang dan jasa juga belum menyelesaikan pekerjaannya, maka pihak pemberi kerja dapat memutuskan secara sepihak surat perjanjian pemborongan pekerjaan dengan ketentuan bahwa pihak penyedia barang dan jasa dikenakan blacklist dan tidak diperbolehkan mengikuti tender di PT PLN (PERSERO) Sektor Pembangkitan Sumatera Bagian Utara Sektor Pembangkitan Labuhan Angin selama 2 (dua) tahun.

e. Apabila dalampelaksanaan pekerjaan terjadi kecelakaan, kerusakan, kebakaran atau kehilangan akibat kesalahan atau kelalaian penyedia barang dan jasa yang menimbulkan kerugian bagi pemberi pekerjaan, maka penyedia barang dan jasa harus mengganti ganti rugi kepada pihak pemberi pekerjaan yang jumlahnya sebanding dengan kejadian yang diderita .

f. Apabila di kemudian hari terbukti hasil pekerjaan tidak sesuai dengan yang dipersyaratkan atau terdapat cacat atau kerusakan yang tersembunyi, maka penyedia barang dan jasa diwajibkan memperbaiki atau menggantinya.

Apabila terjadi keadaan memaksa (force majeure) maka kontraktor harus mengambil langkah-langkahuntuk mencegah kemungkinan terjadinya kerugian yang lebih besar.Untuk keperluan perhitungan kerugian yangmungkin terjadi,kontraktor perlu segera melaporkankepada pihak pemberipekerjaan secara tertulis yang harus sudah diterima dalam waktu 14 (empat belas ) hari kalender terhitung sejak terjadinya force majeure dan pemberi pekerjaan harus memberikan putusan paling lambat 14 hari setelah laporan tertulis tersebut diterima.

Dalam perjanjian pengadaan barang dan jasa yang diadakan antara PT PLN (PERSERO ) Pembangkitan Sumatera Bagian Utara Sektor Pembangkitan Labuhan Angin dan kontraktor,dicantumkan hal-hal yang dapat dianggap sebagai suatu keadaan memaksa (force majeure). Hal-hal tersebut ialah :

a. Bencana alam (gempa bumi,tanah longsor,badai/topan,gunung meletus,petir,epidemi dan banjir)

b. Perang,pemogokan,demonstrasi,blokade,pemberontakan,kerusuhdan kekacauan.

c. Kebakaran (kecuali disebabkan dalam pelaksanaan pekerjaan atau kelalaian pemborong)

d. Keadaan memaksa yang diumumkan secara resmi oleh pemerintah

e. Kebijakan pemerintah dalam bidang moneter.

Tanggung jawab kontraktor dalam pengadaan barang dan jasa apabila terdapat subkontraktormenurut penulis secara yuridis hubungan hukum sub-kontraktorhanya dengan kontraktor utamanya saja, yangdituangkan dalam perjanjian tersendiri. Pihak kontraktor tidak dibenarkan mensub-kontraktor seluruh pekerjaan dan atau sebagian pekerjaan utamanya kepada pihak lain atau pemboronglainnya, kecuali disub-kontrakkan kepada penyedia jasa spesialis dan harus memiliki izin tertulis dari Pihak Pemberi pekerjaan. Dan apabila ketentuan ini dilanggar maka kontrak pengadaan barang atau jasa dapat dibatalkan danterhadap pelanggaran tersebut maka pihak pemborong dapat dikenakan sanksi berupa denda yang bentuk dan besarnya sesuai dengan ketentuan yang telah diatur dalam kontrak. Untuk menghindariterjadinya kerugianmaka kontraktor harus benar-benar memilih subkontraktor yang memilih reputasi yang baik, bertanggung jawabdan memiliki kemapuan yang dapat diandalkan.

Bagi pemborong yang hanya melaksanakan pekerjaan saja, kemudian terjadi kerusakan sebelum pekerjaan diserahkan maka resiko ada pada pemborong yaitu hanya 
bertanggungjawab terbatas pada kesalahan yang dibuatnya (Pasal 1606 Kitab UndangUndang Hukum Perdata).Sekalipun tidak ada kesalahan pada pemborong, ia tetap tidak berhak menerima pembayaran biaya borongan.Hal demikian adalah sesuai dengan pembebanan risiko pada perjanjian timbalebalik pada umumnya yaitu jika pihak yangsatu terhalang untuk memenuhi prestasi maka pihak yang lain juga dibebaskan dari kewajibannya.Dalam keadaan demikian diatas si pemborong dapat juga berhak atas pembayaran pengerjaan barang tersebut jika si pemberi tugas lalai untuk melakukan pemeriksaan dan menyetujui pekerjaan atau bendanya menjadi rusak karena cacat.

\section{Kesimpulan Dan Saran}

1) Hubungan yang terjadi antara pengguna jasa pemborongan dan penyedia jasa pemborongan adalah hubungan hukum untuk melakukan suatupekerjaan tertentu bagi pengguna jasa pemborongan dan sebagai kompensasinya penyedia jasa pemborongan mendapatkan sejumlah pembayaran yang telah ditetapkan maka, pelaksanaan perjanjian pengadaan barang dan jasa di CV Putri Mandiri Sejati Medan dilaksanakan berdasarkanPasal 1601,Pasal 1320, Pasal 1338, Pasal 1340 Kitab Undang-Undang Hukum Perdata danKeputusan Direksi PT PLN (PERSERO) No.3056.K/SDM.00.03/DIR/2016 tanggal 14 Desember 2016 dan berdasarkan Surat Kuasa General Manajer PT PLN (Persero) Pembangkitan Sumatera Bagian Utara Sektor Pembangkitanlabuhan. Dalam proses pengadaan barang dan jasa panitia lelang/negosiasi harus menerapkan prinsip-prinsip keterbukaan,adil, tidak memihak dan obyektif untuk menghindari terjadinya KKN dalam pelaksanaanya. Pemberian akses dan perlakuan yang sama kepada setiap peserta lelang/pengadaan adalah suatu keharusan dalam setiap pelaksanaan perjanjian pemborongan. Perlu peran serta aktif kedua belah pihak dalam perumusan perjanjian agar perjanjian yang akan ditandatangani tersebut menjadi dasar pelaksanaan kerja yang memberikan perlindungan hukum kepada kedua belah pihak secara seimbang.

2) Tanggungjawab Kontraktor CV Putri Mandiri Sejati Medan dalam pengadaan barang dan jasa yaitu lahir berdasarkan prestasi yang diatur dalam Pasal 1234 Kitab Undang-Undang Hukum Perdata. Dengan demikian bahwa dalam setiap perjanjian prestasi merupakan suatu yang wajib dipenuhi oleh debitur dalam setiap perjanjian. Mengenai hak dan kewajiban para pihak dalam perjanjianpemborongan pengadaan Dalam Undang - Undang Nomor 30 Tahun 1999pasal 1 ayat 10 tentang penyelesaian perselisihan perjanjian diluar pengadilan .Dalam praktek penyelesaian perselisihan perjanjian pemborongan dilakukan secara musyawarah.Apabila perselisihan tersebut tidak dapat diselesaikan secara musyawarah maka akan diselesaikan oleh suatu badan arbitase. Keputusan badan arbitrase ini mengikat kedua belah pihak, dan biaya penyelesaian perselisihan yang dikeluarkan akan dipikul bersama. Apabila putusan Badan Arbitrase tidak dapat diterima oleh para pihak maka perselisihan akan diteruskan dan diputuskan melalui Pengadilan Negerisetempat .Dalam prakteknya selama ini, setiap perselisahan dalam pelaksanaan perjanjian pemborongan dapat diselesaikan secara musyawarah dan mufakat diantara para pihak dan belum pernah diselesaikan melalui Badan Arbitrase atau pengadilan. Penyelesaian permasalahan secara musyawarah dalam pelaksanaan perjanjian merupakan langkah yang paling tepat dan efisien karena pada prinsipnya pihak kontraktor dan pihak pengguna jasa sama-sama berkepentingan untuk menyelesaikan pekerjaan sesuai perencanaan.Dan hal-hal 
yang belum diatur dalam perjanjian kerja dapat diatur lebih lanjut dalam suatu addendum-addendum yang merupakan bagian yang tidak terpisahkan dari perjanjian pokok.

\section{DAFTAR PUSTAKA}

\section{Buku dan Jurnal}

Abdul Khakim, 2017, Aspek Hukum Perjanjian Kerja,Peraturan Perusahaan, Dan Perjanjian Kerja Bersama (PKB) , Bandung, Citra Aditya Bakti.

Abdul Kadir Muhammad, 1992, Hukum Perikatan, Bandung, Citra Aditya Bakti.

Adrian Sutedi, 2008, Aspek Hukum Pengadaan Barang Dan Jasa Dan Berbagai Permasalahannya, Jakarta Sinar Grafika Offset

Ahmadi Miru, Hukum Perikatan Penjelasan Pasal 1233 sampai 1456 BW, Jakarta, Raja Grafindo Persada.

Badan Pendidikan dan Pelatihan Keuangan, 2007, Pelaksanaan Pengadaan Barang dan Jasa Pemerintath Bahan Ajar DTSS Pengadaan Barang dan Jasa, Jakarta.

Bambang Waluyo ,1996, Penelitian Hukum Dalam Praktek, Jakarta, Sinar Grafika.

Dumialdji, 2012, Hukum Bangunan, Dasar-dasar Hukum Dalam Proyek dan Sumber Daya Manusia,Jakarta, Sinar Grafika.

Djaja S Meliala, 2014, Hukum Perdata Dalam Perspektif BW, Bandung ,Nuansa Aulia. Hukum Universitas Muhammadiyah Surakarta.

Hutabarat, I. M. ., Martono Anggusti, \& Tobing, C. N. . (2021). TANGGUNG JAWAB PERUSAHAAN ALIH DAYA TERHADAP PEKERJA OUTSOURCHING YANG TERKENA PEMUTUSAN HUBUNGAN KERJA DIMASA PANDEMI COVID-19 (STUDI DOKUMEN PERJANJIAN PENYEDIA JASA DI PT NTU). Nommensen Journal of Legal Opinion, 2(01), 55-79. https://doi.org/10.51622/njlo.v2i01.210

Kansil dan Cristine, 1995, Hukum Perusahaan Indonesia, Jakarta. Pradnya Paramita.

Khusdaifah Dimyanti dan Kelik.Wardiono,2004, Metode Penelitian Hukum,S urakarta Fakultas Hukum.

Kitab Undang-Undang Hukum Perdata Burgerlijk Wetbook, BAB II, Perikatan Yang Lahir dari Kontrak / PersetujuanBagian I.

Munir Fuadi, 2014, Konsep Hukum Perdata, Depok, Rajagrafindo Persada.

M.Syamsudin ,2007, Operasionalisasi Penelitian Hukum, Jakarta, Raja Grafindo.

Salim HS, 2013, Hukum Kontrak Teori Teori Penyusunan Kontrak, Jakarta ,SinarGrafika.

Simamora, Janpatar., Tafsir Makna Negara Hukum dalam Perspektif Undang-Undang Dasar Negara Republik Indonesia Tahun 1945, Jurnal Dinamika Hukum FH Universitas Jenderal Soedirman, Vol. 14 No. 3 September 2014.

Siallagan, Haposan dan Simamora, Janpatar., Hukum Tata Negara Indonesia, Medan: UD. Sabar, 2011.

Subekti, 1987, Pokok-Pokok Hukum Perdata, Bandung, Intermasa.

Soerjono Soekanto ,1986,Pengantar Penelitian Hukum, Jakarta : UI- Press.

Toman Sony Tambunan, 2019, Hukum Bisnis, Jakarta, Prenamedia Group.

Patrik Purwahid, 1986, Asas Itikad Baik dan Kepatutan dalam Perjanjian, Semarang, Badan Penerbit UNDIP.

Peter Mahmud Marzuki, 2008, Pengantar Ilmu Hukum, Jakarta, Prenada Media Group.

R. Setiawan, 2007, Pokok-pokok Hukum Perikatan, Bandung, Putra Abardin.

R.Subekti, 1970, Hukum Perjanjian, Jakarta , Pembimbing Masa.

R. Wiryono Projodikoro, 1993, Asas-asas Hukum Perjanjian, Bandung, Sumur. 